\title{
Vended foods in Lagos, Nigeria: A potential reservoir for the spread of emerging strains of drug resistant bacteria
}

\author{
Kabiru Olusegun Akinyemi", Muibat O. Fashola, Nene Habib, Esther Akinwande \\ Department of Microbiology, Faculty of Science, Lagos State University, Lagos, Nigeria; \\ ${ }^{\#}$ Corresponding Author: akinyemiko@yahoo.com
}

Received 25 February 2013; revised 27 March 2013; accepted 5 April 2013

Copyright (C) 2013 Kabiru Olusegun Akinyemi et al. This is an open access article distributed under the Creative Commons Attribution License, which permits unrestricted use, distribution, and reproduction in any medium, provided the original work is properly cited.

\section{ABSTRACT}

Background and Aims: Food is of paramount importance to the sustenance of human health, on that basis this study was initiated with a view to determining bacterial agents associated with the vended foods and to investigating antibacterial resistance of the isolates. Methods: Twelve food samples from vendors were randomly collected from ten locations within Lagos environs. The food samples were analyzed bacteriologically by standard methods. The isolates were identified and subjected to antimicrobial susceptibility testing using standard procedures. Results: The total plate counts of bacteria recorded was between $2.98 \times 10^{3} \mathrm{cfu} / \mathrm{g}$ in Jollofrice and $4.09 \times 10^{4} \mathrm{cfu} / \mathrm{g}$ in Salad. Seventy-six bacterial isolates made up of six genera; Escherichia coli, Salmonella Typhimurium, Alcaligenes spp., Klebsiella pneumoniae, Enterobacter spp., Serratia marcensens and Proteus spp. were identified. Most of the bacterial isolates were moderately sensitive to cotrimoxazole, nalidixic acid, amoxicillin and nitrofurantion except in S. Typhimurium with less than $50 \%$ susceptibility. Also over $60 \%$ of the pathogens isolated were inhibited by ceftazidime, cefpodoxime, and levofloxacin antibiotics and most strains of E. coli, S. Typhimurium and K. pneumoniae were resistant to ofloxacin, ciprofloxacin and ceftriazone. Conclusion: The study revealed gross contamination of various vended foods. It

\footnotetext{
*Ethical Approval: Ethical approval of the ethical committee of the University sought.

Competing Interest: We declared that there are no competing interests. Funding: Funding from the monthly research allowance received from the University.
}

also indicated that vended foods are potential reservoir for the spread of emerging multiple drug resistant bacteria strains that pose threat to public health. There is a need for intensive surveillance to avoid possible outbreak of foodborne diseases resulting from consumption of contaminated vended foods.

Keywords: Antibiotics; Bacteria; Contamination; Reservoir; Resistance; Vended Foods

\section{INTRODUCTION}

Food is of paramount importance to the sustenance of human health. However, the preparations of food usually result into their inadvertent contamination [1]. In developing countries wide variety of foods, which include vegetables, confectionary meat and meat products and poultry are usually prepared by food vendors. Streetvended foods provide a source of inexpensive, convenient and often nutritious food for urban and rural poor; a major source of income for a vast number of persons, particularly women; and a chance for self-employment and the opportunity to develop business skills with low capital investment $[2,3]$. In Nigeria, vended food is intimately connected with take-out, junk food, snacks, and fast food; it is distinguished by its local flavour and by being purchased on the street, with or without entering any building. Both take-out and fast food are often sold from counters inside buildings [4]. In spite of numerous advantages offered by street foods, there are also several health hazards associated with this sector of the economy The problems associated with the methods of consumption of vended foods considerably arise from traditional processing and packaging, improper handling temperature, poor personal hygiene of food handlers. Contami- 
nation of vended food may occur during and after processing of such food. Contamination of ready-to-eat food by organisms such as Escherichia coli, Klebsiella spp., Proteus spp., Salmonella spp., Pseudomonas spp. and Enterobacter spp. from vended foods [5] is of primary concern because of the risk of these organisms in the outbreak of food-borne diseases such as gastroenteritis, dysentery, typhoid fever etc. and may as well serve as reservoir of genes for antimicrobial resistance in pathogenic organisms [5]. Recently, there has been increasing patronage of vended foods in Lagos by citizenry due to its easy access, cheapness and affordability. This has led to unprecedented upsurge food vendors seen on the streets of Lagos particularly by the road sides coupled with noticeable increase in cases of diarrhoea-associated illnesses and concomitant treatment failure. It was in line with this that the present study was initiated with a view to determining bacterial agents associated with the vended foods and to investigating antibacterial resistance of the isolates.

\section{MATERIALS AND METHODS}

Sample source, environment and collection: Food samples were obtained from ten eatery sources within Lagos environs namely Tantalizers (Apapa), Mama cass (Apapa), Iya Eli (Cele Expressway), Destiny Restaurant (Oshodi), Mama Paul (Ajegunle), Jato food restaurant (Ikotun), Spices (Idi Araba], Mama Ngozi (Ilasa), Iya Afiz (Lasu), Mama beneh (waterside). The food samples collected were Eba, Amala, Jollof Rice, Fried Rice, Beans, Moimoi, Dodo, White Rice, Fried Fish, Salad and Ewedu were labeled as EB, AM, JR, FR, B, MM, WR, FF, SD and EW respectively. The vending locations were poorly sanitized, and dishes were exposed (Figures 1 and 2) except in one or two places where high level of hygiene was maintained. Most of the food vendors recruited in the study were randomly sampled and were mostly female subjects within the age group 18 to 35 years. The food samples were aseptically collected into ice-packed sterile container in duplicates and transported to the laboratory within two hours for bacteriological examinations.

Bacterial enumeration and isolation: Samples were processed as described by Umoh and Odoba [6]. In brief, each food sample obtained was separately blended. Ten [10] gram of each of sample was introduced into $90 \mathrm{ml}$ of sterilized physiological saline [0.85 w/v], homogenized and serially diluted. This was followed by the inoculation on solid media; Nutrient agar [NA], MacConkey agar (MCA) and Salmonella-Shigella agar (SSA). All inoculated agar plates were incubated at $37^{\circ} \mathrm{C} \pm 2^{\circ} \mathrm{C}$ for 18 to 36 hours. After incubation, viable colonies were enumerated by standard procedure. Subcultures were made on Eosin methylene blue agar (EMBA) and MacConkey
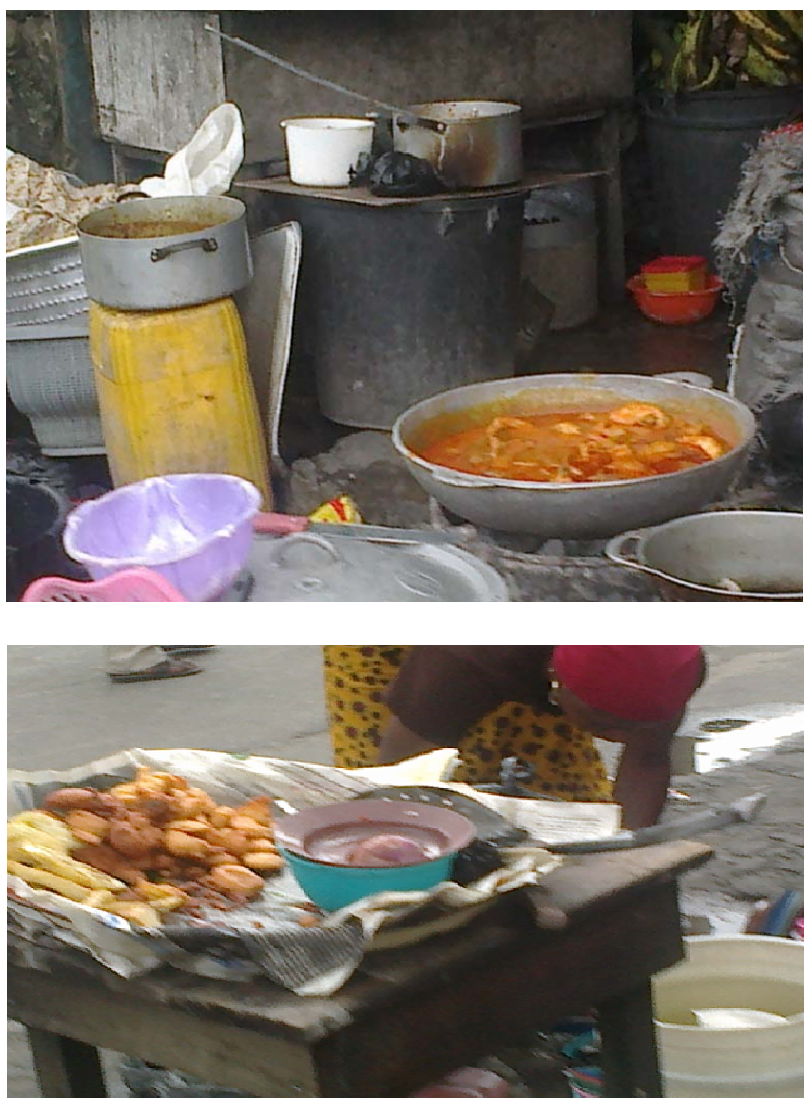

Figure 1. Scenes of exposed dishes from an investigated vended food at Ajegunle and Idi-Araba restaurants in Lagos.

agar (MCA) (Oxoid) for the isolation of Escherichia coli and Enterbacter aerogenes. Salmonella-Shigella agar (Oxoid) was used for the non-lactose fermenting bacteria. All the inoculated media were incubated aerobically at $37^{\circ} \mathrm{C}$ for 24 hours. Isolates were then identified by combination of colonial and morphological characterization on solid media together with standard biochemical reactions as described by Cowan and Steel [7]. The commercially-available identification system API 20E (bioMérieux, France) was used. Colonies considered to be Salmonella spp. were further tested for somatic $(\mathrm{O})$ and flagella $(\mathrm{H})$ antigens with polyvalent antisera (Wellcome Diagnostic, UK).

Antimicrobial susceptibility testing: All bacteria isolates were investigated for their in vitro susceptibilities to 17 antibiotics by disk diffusion as described by Clinical and Laboratory Standard Institute (CLSI; formerly NCCLS) guidelines [8]. Three to five colonies were inoculated into a tube containing tryptic soy broth (Difco, USA), incubated overnight at $37^{\circ} \mathrm{C}$. Standardization of the inoculums was performed by diluting the broth cultures until turbidity matched the $0.5 \mathrm{McF}$ arland standards. A sterile cotton swab was dipped into the standardized suspension, drained, and used for inoculating $20 \mathrm{~mL}$ of Mueller-Hinton agar in a $100-\mathrm{mm}$ disposable plate (Ster- 


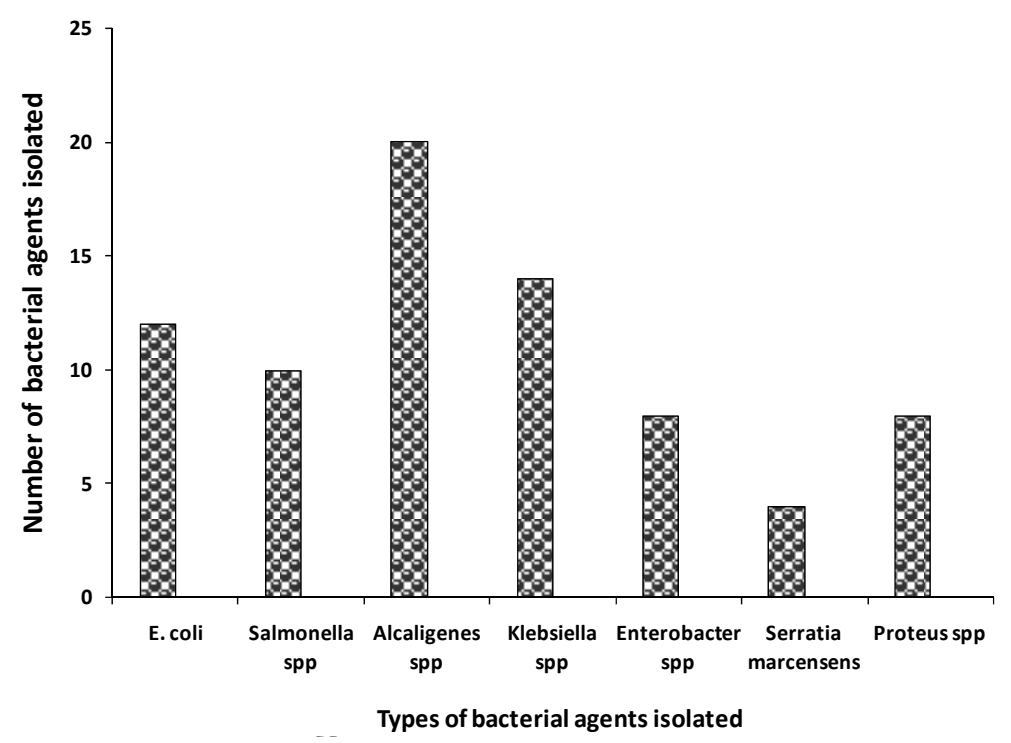

Figure 2. Bacterial agents isolated from vended foods in Lagos, Nigeria.

lin, UK). The inoculated plates were air-dried, and antibiotic discs (Oxoid, UK) were placed on the agar using flamed forceps and were gently pressed down to ensure contact. The discs with the following were used for susceptibility testing: Ofloxacin $(20 \mu \mathrm{g})$, Cefpodoxime (30 $\mu \mathrm{g})$, Levofloxacin, Nitrofurantoin $(30 \mu \mathrm{g})$, Augmentin $(30 \mu \mathrm{g})$, Amoxicillin $(25 \mu \mathrm{g})$, Nalidixic Acid $(30 \mu \mathrm{g})$, Ceftriaxone $(30 \mu \mathrm{g})$, Gentamycin $(10 \mu \mathrm{g})$, Cephacetril $(30 \mu \mathrm{g})$, Tetracycline, $(30 \mu \mathrm{g})$, Cephadroxil $(30 \mu \mathrm{g})$, Ciprofloxacin $(20 \mu \mathrm{g})$, Oxacillin $(25 \mu \mathrm{g})$, Cefuroxime $(30 \mu \mathrm{g})$, Cotrimoxazole $(25 \mu \mathrm{g})$, Ceftazidime $(30 \mu \mathrm{g})$ (Oxoid, UK). The plates were incubated aerobically at $37^{\circ} \mathrm{C}$ for $18-24$ hours. The diameter of the zones of inhibition were measured with a ruler and compared with a zone-interpretation chart [9]. Escherichia coli ATCC 25922 was used as control.

\section{RESULTS}

The vended food samples analyzed in this study were contaminated with at least two members of bacteria in the family enterobacteriaceae (Table 1). The total plate counts (TPC) of bacteria recorded in the food samples ranged from $2.98 \times 10^{3} \mathrm{cfu} / \mathrm{g}$ in Jollof-rice, to $4.09 \times 10^{4}$ $\mathrm{cfu} / \mathrm{g}$ in Salad. Seventy-six bacterial isolates made up of six genera; Escherichia coli, Salmonella Typhimurium, Alcaligenes spp., Klebsiella pneumoniae, Enterobacter spp., Serratia marcensens and Proteus spp. were identified. Alcaligenes spp. was most frequently encountered pathogen $(26 \%)$, isolated from six of the 12 vended food samples evaluated. This was closely followed by Klebsiella pneumoniae (18.4\%) and the least was Serratia marcensens (5\%), isolated only from Eba sample (Table 1 and Figure 2).

Antimicrobial susceptibility tests revealed that most of
Table 1. Plate counts of the bacterial agents from vended foods in Lagos.

\begin{tabular}{|c|c|c|}
\hline Food items & $\begin{array}{l}\text { Bacterial count (mean } \\
\text { TPC) }\left(\times 10^{3}\right)(\mathrm{cfu} / \mathrm{g})\end{array}$ & Organism(s) isolated \\
\hline Eba & 3.52 & Serratia mascensens \\
\hline Amala & 3.3 & $\begin{array}{l}\text { Alcaligenes spp. } \\
\text { Klebsiella spp. }\end{array}$ \\
\hline Ewedu & 3.46 & $\begin{array}{c}\text { Proteus spp. } \\
\text { E. coli } \\
\text { Klebsiella spp. }\end{array}$ \\
\hline Jollof rice & 2.98 & Proteus spp. \\
\hline Fried rice & 3.84 & $\begin{array}{l}\text { Alcaligenes spp. } \\
\text { Salmonella spp. }\end{array}$ \\
\hline Beans & 3.2 & $\begin{array}{l}\text { Alcaligenes spp. } \\
\text { Salmonella spp. }\end{array}$ \\
\hline Moi moi & 3.05 & $\begin{array}{c}\text { Alcaligenes spp. } \\
\text { Proteus spp. }\end{array}$ \\
\hline Fried fish & 3.68 & $\begin{array}{l}\text { Enterobacter spp. } \\
\text { Alcaligenes spp. }\end{array}$ \\
\hline Dodo & 3.02 & $\begin{array}{l}\text { Alcaligenes spp. } \\
\text { Enterobacter spp. }\end{array}$ \\
\hline Salad & 40.9 & $\begin{array}{l}\text { Proteus spp. } \\
\text { Salmonella spp. }\end{array}$ \\
\hline
\end{tabular}

Mean TPC $=$ Mean value of three samples replicate.

the conventional antibiotics particularly, cotromoxazole, nalidixic acid, amoxicillin and nitrofurantion were moderately sensitive against bacterial agents isolated from vended food samples, except in S. Typhimurium where less than $50 \%$ of the strains were inhibited (Table 2). In this study $83.3 \%, 80 \%$ and $71.4 \%$ of E. coli, S. Typhimurium and K. pneumoniae respectively were resistant to tetracycline. It is worthy of note that $50 \%$ of the most frequently isolated pathogen (Alcaligenes spp.) developed resistance to this antibiotic (Table 2). The result also 
Table 2. Resistance patterns of bacterial agents from vended food against conventional antibiotics.

\begin{tabular}{|c|c|c|c|c|c|c|c|c|}
\hline \multirow{2}{*}{ Bacterial agents } & \multirow{2}{*}{ Frequency } & \multicolumn{7}{|c|}{ Antibiotics evaluated } \\
\hline & & AUG & GEN & NAL & NIT & COT & AMX & TET \\
\hline E. coli & 12 & $6(50 \%)$ & $4(33.3 \%)$ & $6(50 \%)$ & $2(16.7 \%)$ & $4(33.3 \%)$ & $4(33.3 \%)$ & $10(83.3 \%)$ \\
\hline Salmonella spp. & 10 & $6(60 \%)$ & $8(80 \%)$ & $6(60 \%)$ & $0(0 \%)$ & $4(40 \%)$ & $4(40 \%)$ & $8(80 \%)$ \\
\hline Alcaligenes spp. & 20 & $6(30 \%)$ & $4(20 \%)$ & $0(0 \%)$ & $2(10 \%)$ & $6(30 \%)$ & $6(30 \%)$ & $10(50 \%)$ \\
\hline Klebsiella spp. & 14 & $4(28.6 \%)$ & $8(57.1 \%)$ & $4(28.6 \%)$ & $4(28.6 \%)$ & $4(28.6 \%)$ & $0(0 \%)$ & $10(71.4 \%)$ \\
\hline Enterobacter spp. & 8 & $4(50 \%)$ & $6(75 \%)$ & $2(25 \%)$ & $2(25 \%)$ & $2(25 \%)$ & $4(50 \%)$ & $4(50 \%)$ \\
\hline Serratia mascences & 4 & $2(50 \%)$ & $0(0 \%)$ & $0(0 \%)$ & $0(0 \%)$ & $0(0 \%)$ & $0(0 \%)$ & $0(0 \%)$ \\
\hline Proteus spp. & 8 & $2(25 \%)$ & $0(0 \%)$ & $2(25 \%)$ & $2(25 \%)$ & $2(25 \%)$ & $4(50 \%)$ & $2(25 \%)$ \\
\hline Total & 76 & $30(39.5 \%)$ & $30(39.5 \%)$ & $20(26.3 \%)$ & $12(16 \%)$ & $22(28.9 \%)$ & $22(28.90 \%)$ & $44(57 \%)$ \\
\hline
\end{tabular}

KEY: AUG = Augmentin; GEN = Gentamycin; NAL = Nalidixic Acid; NIT = Nitrofurantoin; COT = Cotrimoxazole; AMX = Amoxicillin; TET = Tetracycline.

revealed that ceftazidime, cefpodoxime, and levofloxacin inhibited over $60 \%$ of the pathogens isolated. Most of the strains of E. coli, S. Typhimurium and K. pneumoniae were resistant to ofloxacin, ciprofloxacin and ceftriazone. Proteus spp. was highly sensitive to cephacetril, whereas $K$. pneumoniae strains were moderately sensitive to this antibiotic. Over $50 \%$ of Alkaligenes spp were inhibited by the fluoroquinolone and third generation cephalosporins evaluated except cefuroxime and cephadroxil antibiotics which were inactive (Table 3).

\section{DISCUSSION}

In the study, total plate counts (TPC) of bacteria recorded in the food samples ranged from $2.98 \times 10^{3} \mathrm{cfu} / \mathrm{g}$ to $4.09 \times 10^{4} \mathrm{cfu} / \mathrm{g}$, indicating that all the 12 different vended food samples evaluated were grossly contaminated. Previous studies elsewhere had revealed that most processed or unprocessed food contain different bacterial agents at varying amount and serve as good substrate for microbial metabolism [10]. Highest bacteria counts (4.1 $\times 10^{4} \mathrm{cfu} / \mathrm{g}$ ) in salad food sample followed by fried rice $\left(3.8 \times 10^{3} \mathrm{cfu} / \mathrm{g}\right)$, and fried fish $\left(3.68 \times 10^{3} \mathrm{cfu} / \mathrm{g}\right)$. This result was not surprising, because of the exposure of these food samples to the atmosphere, coupled with storage temperature abuse while displaying the food items for sale to the public (Figure 1) might be responsible. This finding was consistence with several reports that street vended foods such as salads, macaroni, fufu, omotuo and red pepper usually had unacceptable levels of contamination $[5,10,11]$. We recorded in this study 76 bacterial isolates made up of six genera: Escherichia coli, S. Typhimurium, K. pneumoniae, Enterobacter spp., Serratia marcensens, Proteus spp. and Alcaligenes spp. all in the enterobacteriaceae family (Table 1 and Figure 2). Alcaligenes spp. was the frequently encountered organisms appearing in $50 \%$ of the different vended foods analyzed. Though Alcaligenes spp. is not usually considered as a pathogen, it has the ability to cause opportunis- tic infections especially in urinary tract infections [12]. Salmonella has been known to cause varying degree of salmonellosis in some improperly cooked food and street vended foods $[2,13]$. In Nigeria, S. Typhimurium-associated gastroenteritis is the most common manifestation of non-typhoidal salmonellosis [14]. Moreover, the presence of Escherichia coli and Enterobacter spp. in food samples like salad, coleslaw and fruit salad calls for concern as these organisms are indicator of faecal contamination [5,15]. Similarly, Enterobacter spp., Serratia marcensens and Proteus spp. had been implicated in many diseases including gastroenteritis [16]. Possible sources of contamination in this study could be hands of the handlers; food ingredients used and even water. Water is a critical raw material in many street food vending operations. Close observations showed that well waters were used for washing and preparing the vended foods samples analyzed. Our recent reports had indicated gross contamination of well waters which form major source of drinking water in Lagos and its environs [17,18]. Contaminated water had been reported to create a public health risk if it is used for drinking purposes, washing of food, processing of food, washing of equipment and utensils $[19,20]$. Therefore, the presence of members of bacteria in the family enterobacteriaceae in food products is usually seen as a threat or a major health risk to microbial safety of the food [5,21], an indication of low microbial quality of vended foods found within the Lagos metropolis.

Most of the bacterial isolates from vended foods in this study were moderately sensitive to cotromoxazole, nalidixic acid, amoxicillin and nitrofurantion except in $S$. Typhimurium with less than $50 \%$ susceptibility (Table 2). Over $70 \%$ of E. coli, S. Typhimurium and K. pneumoniae were resistant to tetracycline. This observation was expected as the efficacy of the first line antibiotics had been doubtful in the recent past because of its abuse [5,17]. In a similar study conducted in south-west Nigeria, 53.85\% of the organisms isolated from vended foods were resis- 
Table 3. Susceptibility patterns of bacterial agents from vended food against flouroquinolones and third generation cephalosporins.

\begin{tabular}{cccccccccccc}
\hline Bacterial agents & Frequency & OFL & CPX & CAZ & CPD & CXM & CEP & LEV & CRO & CEF & OXV \\
\hline E. coli & 12 & $0(0 \%)$ & $4(33.3 \%)$ & $8(66.6 \%)$ & $10(83.3 \%)$ & $0(0 \%)$ & $2(16.7 \%)$ & $6(50 \%)$ & $4(33.3 \%)$ & $2(16.7 \%)$ & $10(83.3 \%)$ \\
Salmonella spp. & 10 & $2(20 \%)$ & $2(20 \%)$ & $8(80 \%)$ & $8(80 \%)$ & $4(40 \%)$ & $0(0 \%)$ & $8(80 \%)$ & $0(0 \%)$ & $4(40 \%)$ & $2(20 \%)$ \\
Alcaligenes spp. & 20 & $10(50 \%)$ & $12(60 \%)$ & $16(80 \%)$ & $18(90 \%)$ & $8(40 \%)$ & $0(0 \%)$ & $12(60 \%)$ & $14(70 \%)$ & $12(60 \%)$ & $20(100 \%)$ \\
Klebsiella spp. & 14 & $8(57.1 \%)$ & $8(57.1 \%)$ & $10(71.4 \%)$ & $8(57.1 \%)$ & $8(57.1 \%)$ & $0(0 \%)$ & $10(71.4 \%)$ & $6(42.8 \%)$ & $8(57.1 \%)$ & $14(100 \%)$ \\
Enterobacter spp.. & 8 & $4(50 \%)$ & $0(0 \%)$ & $8(100 \%)$ & $4(50 \%)$ & $4(50 \%)$ & $0(0 \%)$ & $4(50 \%)$ & $6(75 \%)$ & $2(25 \%)$ & $0(0 \%)$ \\
Serratia mascences & 4 & $4(100 \%)$ & $4(100 \%)$ & $4(100 \%)$ & $4(100 \%)$ & $2(50 \%)$ & $0(0 \%)$ & $4(100 \%)$ & $4(100 \%)$ & $2(50 \%)$ & $4(100 \%)$ \\
Proteus spp. & 8 & $6(75 \%)$ & $6(75 \%)$ & $6(75 \%)$ & $4(50 \%)$ & $4(50 \%)$ & $0(0 \%)$ & $6(75 \%)$ & $6(75 \%)$ & $6(75 \%)$ & $2(25 \%)$ \\
Total & 76 & $(44.7 \%)$ & $(47.3 \%)$ & $(78.9 \%)$ & $(73.6 \%)$ & $(39.4 \%)$ & $(2.6 \%)$ & $(65.7 \%)$ & $(52.6 \%)$ & $(47.3 \%)$ & $(68.4 \%)$ \\
\hline
\end{tabular}

KEY: OFL = Ofloxacin; CPX = Ciprofloxacin; CAZ = Ceftazidime; CPD = Cefpodoxime; CXM = Cefuroxime; CEP = Cephadroxil; LEV = Levofloxacin; $\mathrm{CRO}=$ Ceftriazone; $\mathrm{OXV}=$ Oxacillin $; \mathrm{CEF}=$ Cephacetril.

tant to these antibiotics [20]. Our results indicated also that more than $60 \%$ of the pathogens isolated were inhibited by ceftazidime, cefpodoxime, and levofloxacin antibiotics and most of the strains of E. coli, S. Typhimurium and $K$. pneumoniae were resistant to ofloxacin, ciprofloxacin and ceftriazone. This observation is food for thought, as the only hope of therapy (third generation cephalosporins and fluoroquinolones) for most bacterial diseases and complications in our environment is now threatened. Additionally, more than $80 \%$ of the isolates were resistant to cefuroxime and cephadroxil. This trend is of particular concern because the extended spectrum cephalosporins are the antibiotics of choice for children. [22]. Therefore, the emergence of antibiotic resistant bacterial pathogens from vended food is a new scourge and the explanation for this is inconclusive and difficult. This is because these drugs are relatively expensive and less abuse in Nigeria. However, previous reports have indicated that either clonal spread or resistance due to mutations in chromosomal genes and/or extra-chromosomal genes remain the potential mechanisms for resistance [23], a possibility that could not be ruled out in this study, unfortunately, genetic analysis of the bacterial agents were not carried which of course one of the limitations of this study.

Generally, our study confirmed gross contamination of various vended foods on the street of Lagos. Bacteria members of the family enterobacteriaceae were the organisms implicated and were found to develop resistance to most of the first line antibiotics evaluated. The study also recorded emergence of fluoroquinolones and third generation cephalosporins resistant bacteria strains from vended foods with public health implications. Therefore there is a need for intensive surveillance of vended foods in the State to reduce microbial risk associated with their consumption. The need to cover all the opened vended foods by the vendors of these foods is essential to pre- vent contamination. While public enlightenment to discourage the patronage of vended foods should be intensified, the need to imbibe high level of hygienic practice by food vendors should be promoted. Furthermore, it is hope that Food Regulatory Authorities will rise up to its responsibilities by ensuring close monitoring of vended foods and quality of various foods sold to the general public, to avoid possible outbreak of food-borne diseases resulting from consumption of contaminated vended foods.

\section{REFERENCES}

[1] Mead, G.C. (2004) Microbiological quality of poultry meat: A review. Brazilian Journal of Poultry Science, 6, 135-142.

[2] WHO (1996) Risk management and food safety, report of the joint FAO/WHO consultation. FAO Food and Nutrition Paper, WHO, Geneva, 65.

[3] Schoeder, C.M., White, D.G. and Meng, J. (2004) Retail meat and poultry as a reservoir of antimicrobial-resistant Escherichia coli. Food Microbiology, 21, 244-255.

[4] Chukuezi, C.O. (2010) Food safety and hygienic practices of street food vendors in Owerri, Nigeria. Studies in Sociology of Science, 1, 50-57.

[5] Oluyege, A.O., Dada, A.C., Ojo, A.M. and Oluwadare, E. (2009) Antibiotic resistance profile of bacterial isolates from food sold on a University campus in south western Nigeria African. Journal of Biotechnology, 8, 5883-5888.

[6] Umoh, V.I. and Odoba, M.B. (1999) Safety and quality evaluation of street foods sold in Zaria, Nigeria. Food Control, 19, 109-110.

[7] Barrow, G.I. and Feltham, R.K.A. (1993) Cowan and steel's manual for the identification of medical bacteria. 3rd Edition, Cambridge University Press, Cambridge, 331.

[8] National Committee for Clinical Laboratory Standards (1999) Performance standards for antimicrobial suscep- 
tibility testing: Ninth informational supplement, v. 19. NCCLS Document No. M-100-S9, National Committee for Clinical Laboratory Standards, Wayne, 1-112.

[9] Bauer, A.W., Kirby, W.M., Sherris, J.C. and Turck, M. (1966) Antibiotic susceptibility testing by a standardized single disk method. American Journal of Clinical Pathology, 45, 493-496.

[10] Mensah, P., Yeboah-Manu, D., Owusu-Darko, K. and Ablordey, A. (2002) Street foods in Accra, Ghana: How safe are they? Bulletin of the World Health Organization, 80, 546-554.

[11] Barro, N., Bello, A., Itsiembou, Y., Savadogo, A. and Ouattara, C.A. (2007) Street-vended foods improvement: Contamination mechanisms and application of food safety objective strategy: Critical review. Pakistan Journal of Nutrition, 6, 1-10. doi:10.3923/pjn.2007.1.10

[12] Mangel, A.R., Johnson, J.R., Foxman, F.O., Bryan, T.T., Fullerton, K.E. and Riley, W.L. (2001) Widespread distribution of urinary tract infections caused by a multidrug resistant Escherichia coli clonal group. New England Journal of Medicine, 345, 1007-1013. doi:10.1056/NEJMoa011265

[13] Schoeder, C.M., White, D.G. and Meng, J. (2006) Retail meat and poultry as a reservoir of antimicrobial resistant Escherichia coil. Food Microbial, 21, 244-255.

[14] Akinyemi, K.O., Bamiro, B.S. and Coker, A.O. (2007) Salmonellosis in Lagos Nigeria: Incidence of plasmodium falciparum-associated co-infection, pattern of antimicrobial resistance and emergence of reduced susceptibility to fluoroquinolones. Journal of Health, Population and Nutrition, 25, 351-358.

[15] Mosupye, F.M. and Van Holy, A. (2003) Microbiological quality and safety of ready-to-eat street-vended foods in Johannesburg, South Africa. International Journal of Food Microbiology, 61, 137-145. doi:10.1016/S0168-1605(00)00264-6

[16] Cheesebrough, M. (2002) District laboratory practices in tropical countries. Part 2. Cambridge University Press, Cambridge, 143-157.

[17] Akinyemi, K.O., Oyefolu, A.O., Salu, B.O., Adewale, A.O. and Fasure, A.K. (2006) Bacterial pathogens associated with tap and well waters in Lagos. East and Central African Journal of Surgery, 11, 110-117.

[18] Akinyemi, K.O., Iwalokun, B.A., Foli, F., Oshodi, K. and Coker, A.O. (2011) Prevalence of multiple drug resistance and screening of enterotoxin gene (stn) in Salmonella enterica serovars from water sources in Lagos, Nigeria. Public Health, 125, 65-71. doi:10.1016/j.puhe.2010.11.010

[19] Barro, N., Bello, A.R., Savadogo, A., Ouattara, C.A.A., Ilboudo, A.J. and Traore, A.S. (2002) Hygienic status assessment of dishwater, utensils, hands and pieces of money in street foods vending sites in Ouagadouguo, Burkina Faso. African Journal of Biotechnology, 2, 1107-1112.

[20] Oladipo, I.C. and Adejumobi, O.D. (2010) Incidence of antibiotic resistance in some bacterial pathogens from street vended food in Ogbomoso, Nigeria. Pakistan Journal of Nutrition, 9, 1061-1068.

[21] WHO (2001) Antimicrobial resistance in shigellosis, cholera and campylobacteriosis. WHO/CDS/CSR/DRS/2001, 8.

[22] Weill, F.X., Demartin, M., Tande, D., Eespie, E. and Patrick, A.D. (2004) SHV-12-like extended-spectrum-betalactamase-producing strains of Salmonella enterica serotypes babelsberg and enteritidis isolated in France among infants adopted from Mali. Journal of Clinical Microbiology, 42, 2432-2437. doi:10.1128/JCM.42.6.2432-2437.2004

[23] Hakanen, A., Kotilianen, P., Huovinen, P., Helenius, H. and Siitonens, A. (2001) Reduced fluoroquinolone susceptibility in Salmonella entrica serotypes in travellers returning from Southeast Asia. Emerging Infectious Diseases, 7, 996-1003. doi:10.3201/eid0706.010613 